\title{
Fitness Exercise Recommendation System Using Weighted Products
}

\author{
Christian Prasetyo ${ }^{1}$, Wirawan Istiono ${ }^{2}$ \\ ${ }^{1}$ Universitas Multimedia Nusantara, Indonesia, christian.prasetyo1@student.umn.ac.id \\ ${ }^{2}$ Universitas Multimedia Nusantara, Indonesia, wirawan.istiono@umn.ac.id \\ Received Date : August 03, 2021 Accepted Date : August 22, 2021 Published Date : September 07, 2021
}

\begin{abstract}
The corona virus pandemic that has been going on since the beginning of 2020 has changed everyone's lifestyle. Even though we are allowed to do activities with health protocols, many people are used to being at home and not exercising so they gain weight. There are also those who want to do fitness exercises but are confused in choosing what type of exercise is appropriate. Doing exercise regularly can help us burn excess calories, but we can't just go on a diet, one of which is to train in the fitness center. So this study discusses the design of a fitness exercise recommendation system using the web-based Weighted Product method. The Weighted Product method evaluates several alternatives to several attributes or criteria, where each attribute is independent of each other. Based on the results of the evaluation of the recommendation system questionnaire to get a success rate of $83.89 \%$, so it can be ascertained that the fitness training recommendation system is successful in implementing the Weighted Product method.
\end{abstract}

Key words: Fitness, Recommendation System, Technology Acceptance Model, Weighted Product.

\section{INTRODUCTION}

The corona virus pandemic that has been going on since the beginning of 2020 has changed the lifestyle of everyone. Even though we are allowed to do activities with health protocols, this pandemic has made many people stay at home and not exercise so they gain weight. There are also those who want to do fitness but don't know what kind of exercise to do. Prevention of excess weight to get the ideal body can be done with exercise [1]-[3]. Doing exercise regularly can help in burning excess calories that we cannot cut by diet alone, one of which is by training in the fitness center [4], [5].

Fitness training is a combination of aerobic capacity, strength and endurance of muscles that can improve health and quality of life (fitness). Fitness is usually synonymous with training in the category of lifting weights, fitness is an aerobic exercise that burns fat and increases muscle mass quickly or just to train fitness [6], [7].
Fitness training is divided into two types, namely weight training and cardio training. This exercise aims to train and build muscle mass and burn fat in certain body parts. By having greater muscle mass, our body's metabolism will automatically be better, that is, the body will burn more calories when we have greater muscle mass. Most people who have just started fitness training find it difficult when they first use exercise equipment in the gym because they do not understand how and their functions [1], [7].

Weighted Product is an example of a solution method that exists in a decision support system. Weighted Product evaluates several alternatives on several attributes or criteria, where each attribute does not depend on each other. Weighted Product uses a multiplication technique in connecting between attribute ratings, where the rating of each attribute will be raised to the power of the associated attribute weight [8]-[10].

\section{STUDY LITERATURE}

Fitness can be mean body health and fit body, which can be combined with regular exercise, consuming healthy food and appropriate nutrition, getting enough rest, thinking positively and avoiding stress. By making exercise a part of a healthy lifestyle, its hope to achieve certain goals [1], [2]. Several kinds of physical development goals are produced such as increased strength, increased flexibility, increased stamina and Improve body composition such as weight loss, weight gain, slimming and muscle building [6].

Decision Support System is defined as a computer-based system composed of three related components, a language system (a mechanism for providing communication between users and other Decision Support System components), a knowledge system (a repository of knowledge about problems contained in a Decision Support System or as a data or a procedure) [11], [12], and a problem processing system (a relationship between two other components, consisting of one or more capabilities in manipulating general problems needed in making a decision) [13], [14]. The steps taken for decision making such as Identify the problem, Determination of method, collecting the data needed to run the decision support model [15], Implementation of the model, evaluate the 
Christian Prasetyo et al., International Journal of Emerging Trends in Engineering Research, 9(9), September 2021, 1234 - 1238

positive side of each available alternative and execute the selected solution [16], [17].

\section{RESEARCH METHOD}

In this study, the first step is to identify the problem. The problem chosen is a system that can recommend the right fitness training to the user. The next step, will do literature review that useful for supporting topics that will explain the theories that support the research topic. What is done is to conduct a literature review and collect data on previous research such as research journals and other students' theses, papers, e-books, official websites and other learning references. And the step is doing analysis that useful for determining the needs in accordance with the specified problem. The author analyzes the features needed in designing and building websites, such as methods, data, and all forms of processes that will be carried out in this study so that they can obtain useful analysis results to recommend types of exercises to users. And the next step is design algorithm and implementation that that will be used for the recommendation system by implementing the Weighted Product method. The design includes making flowcharts and designing User Interfaces. And after the website has been built, the next process is application testing. Testing is done by looking at the accuracy of the output results of this recommendation system.

And last step this research will do evaluation the system that has been made, this step is the process of evaluating the use of the application to the user. Users will be asked to fill out a questionnaire where the results are used as parameters to assess the application. This process will be carried out using the Technology Acceptance Model (TAM).

\section{Result AND ANALysis}

The following are the results and analysis of the implementation of the method that has been done.

\subsection{Scenario}

In this trial, a comparison is made between manual calculations and the results of calculations performed by the system. If the manual calculations and calculations by the application match, then the system can be judged to be running well. In table 1 you can see the data that will be used in this trial.

Table 1: Scenario

\begin{tabular}{|c|c|c|c|c|}
\hline Alternative & \multicolumn{4}{|c|}{ Criteria } \\
\hline $\begin{array}{c}\text { Workout } \\
\text { Name }\end{array}$ & C1 & C2 & C3 & C4 \\
\hline Push A & 67 & 75 & 50 & 26 \\
\hline Push B & 80 & 75 & 50 & 49 \\
\hline Pull A & 67 & 85 & 25 & 26 \\
\hline Pull B & 67 & 75 & 15 & 30 \\
\hline
\end{tabular}

After the weight data is obtained from the system as shown in table 1, the calculation can begin

Table 2: Criteria Weight Value

\begin{tabular}{|c|c|c|}
\hline No & $\begin{array}{c}\text { Criteria } \\
\text { Name }\end{array}$ & Weight \\
\hline C1 & Alat & 3 \\
\hline C2 & Waktu & 2 \\
\hline C3 & Gender & 1 \\
\hline C4 & Weight & 2 \\
\hline
\end{tabular}

The first process carried out is the normalization of the weights of the criteria that have been entered, as shown in Table 3. Multipliers can be especially confusing. Write "Magnetization (kA/m)" or "Magnetization $\left(10^{3} \mathrm{~A} / \mathrm{m}\right)$." Do not write "Magnetization $(\mathrm{A} / \mathrm{m}) \times 1000$ " because the reader would not know whether the top axis label in Figure 1 meant $16000 \mathrm{~A} / \mathrm{m}$ or $0.016 \mathrm{~A} / \mathrm{m}$. Figure labels should be legible, approximately 8 to 12 point type.

Table 3: Weight Normalization

\begin{tabular}{|c|c|c|}
\hline No & Normalization & Result \\
\hline C1 & $3(3+2+1+2)$ & 0.375 \\
\hline C2 & $2(3+2+1+2)$ & 0.25 \\
\hline C3 & $1(3+2+1+2)$ & 0.125 \\
\hline C4 & $2(3+2+1+2)$ & 0.25 \\
\hline
\end{tabular}

After the normalization process has been completed, the next step is to calculate the value of the $\mathrm{S}$ vector. The calculation process is carried out by raising the alternative weight value to the normalized weight value in Table 3 . Then, the weight with the cost rank attribute is negative while the benefit rank attribute is positive. The process of calculating the value of the $S$ vector can be seen in Table 4 .

Table 4: S Vector Calculation

\begin{tabular}{|c|c|c|}
\hline No & Calculation & Result \\
\hline S1 & $\left(67^{0.375}\right)\left(75^{-0.25}\right)\left(50^{0.125}\right)\left(26^{-0.25}\right.$ & $\begin{array}{c}1.1875192235 \\
6\end{array}$ \\
\hline $\mathrm{S} 2$ & $\left(80^{0.375}\right)\left(75^{-0.25}\right)\left(5^{0.125}\right)\left(49^{-0.25}\right)$ & $\begin{array}{c}1.0832174803 \\
8\end{array}$ \\
\hline $\mathrm{S} 3$ & $\begin{array}{l}\left(67^{0.375}\right)\left(85^{-0.25}\right)\left(25^{0.125}\right)\left(26^{-0.25}\right. \\
\end{array}$ & $\begin{array}{c}1.0554131078 \\
9\end{array}$ \\
\hline S4 & $\left(67^{0.375}\right)\left(75^{-0.25}\right)\left(15^{0.125}\right)\left(30^{-0.25}\right.$ & $\begin{array}{c}0.9856978944 \\
6\end{array}$ \\
\hline
\end{tabular}

After getting the results of the calculation of the vector $\mathrm{S}$, the next process is to calculate the value of the vector $\mathrm{V}$ by dividing each vector $S$ by the sum of all the values of the vector $S$. The process of calculating the value of the vector $\mathrm{V}$ can be seen in Table 5 . 
Christian Prasetyo et al., International Journal of Emerging Trends in Engineering Research, 9(9), September 2021, 1234 - 1238

Table 5: V Vector Calculation

\begin{tabular}{|c|l|c|}
\hline No & \multicolumn{1}{|c|}{ Calculation } & Result \\
\hline V1 & $\begin{array}{l}1.18751922356 / 4.31184770 \\
6\end{array}$ & $\begin{array}{c}0.275408433 \\
8\end{array}$ \\
\hline V2 & $\begin{array}{l}1.08321748038 / 4.31184770 \\
6\end{array}$ & $\begin{array}{c}0.251218863 \\
5\end{array}$ \\
\hline V3 & $\begin{array}{l}1.05541310789 / 4.31184770 \\
6\end{array}$ & $\begin{array}{c}0.244770497 \\
4\end{array}$ \\
\hline V4 & $\begin{array}{l}0.98569789446 / 4.31184770 \\
6\end{array}$ & $\begin{array}{c}0.228602205 \\
3\end{array}$ \\
\hline
\end{tabular}

After the $\mathrm{V}$ vector calculation process is complete, the next process is to rank the $\mathrm{V}$ vector values based on the highest value as the final value to be displayed as an exercise recommendation. The ranking of $\mathrm{V}$ vector values can be seen in Table 6.

Table 6: V Vector Ranking

\begin{tabular}{|c|c|c|}
\hline Criteria Name & V Vector & Result \\
\hline Push A & V1 & $\begin{array}{c}0.275408433 \\
8\end{array}$ \\
\hline Push B & V2 & $\begin{array}{c}0.251218863 \\
5\end{array}$ \\
\hline Pull A & V3 & $\begin{array}{c}0.244770497 \\
4\end{array}$ \\
\hline Pull B & V4 & $\begin{array}{c}0.228602205 \\
3\end{array}$ \\
\hline
\end{tabular}

Table 6 shows the results of ranking the vector values of $\mathrm{V}$. The results obtained are compared with the results processed by the system that has been created. The results of the value of the system can be seen in Figure 1.

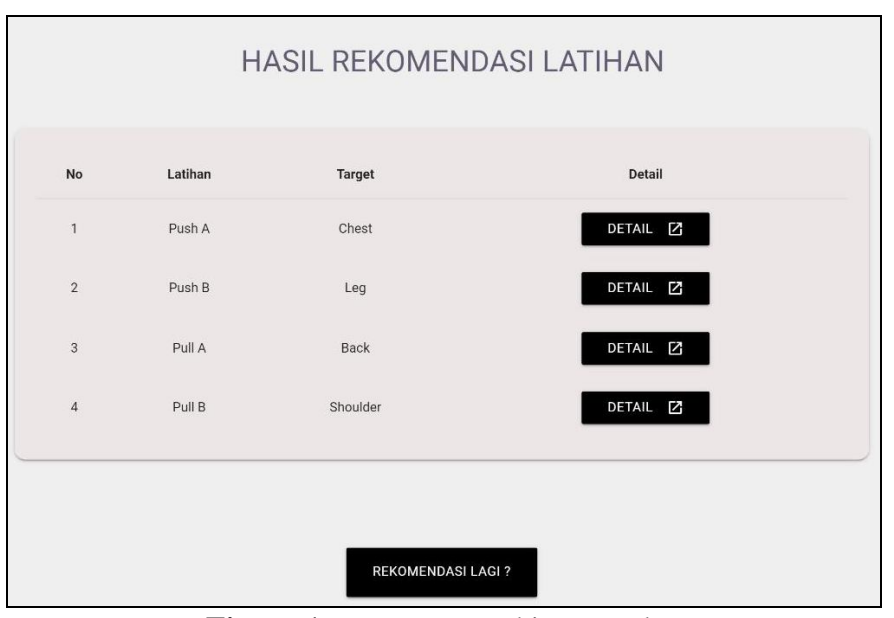

Figure 1: V Vector Ranking Result

Figure 1 shown the result of system calculations. It can be seen in the figure that the results of the data from the system are in accordance with the results of manual calculations contained in table 6 . Then the system can work well and the weighted product method has been successfully implemented in the exercise recommendation system.

\subsection{User Evaluation}

Evaluation to the user is done by asking the user to use the recommendation system application that has been made. Users who have used the recommendation system application are asked to fill out a questionnaire containing questions about the recommendation system application. The questions in the questionnaire used used the Technology Acceptance Model (TAM).

Questionnaires were distributed using google forms to Multimedia Nusantara University students and school friends so that the number of respondents was 35 people. The list of questions used can be seen in table 7 below.

Table 7: Question List

\begin{tabular}{|c|c|}
\hline \multicolumn{2}{|r|}{ Questions } \\
\hline $\begin{array}{l}\text { Perceived } \\
\text { Usefulness }\end{array}$ & $\begin{array}{l}\text { 1. The features of this exercise } \\
\text { recommendation system are easy to access and } \\
\text { use. } \\
2 \text {. This recommendation system makes it } \\
\text { easier for me to choose the type of fitness } \\
\text { training. }\end{array}$ \\
\hline $\begin{array}{l}\text { Perceived } \\
\text { Ease of } \\
\text { Use }\end{array}$ & $\begin{array}{l}\text { 1. Overall this recommendation system is easy } \\
\text { to use. } \\
\text { 2. It didn't take me long to understand how to } \\
\text { use this recommendation system. } \\
\text { 3. The display of this recommendation system } \\
\text { makes it easier for me to use the system. }\end{array}$ \\
\hline $\begin{array}{c}\text { Attitude } \\
\text { Toward } \\
\text { Using }\end{array}$ & $\begin{array}{l}\text { 1. This fitness workout recommendation } \\
\text { system is a great idea to make. } \\
\text { 2. I feel very happy to use this fitness training } \\
\text { recommendation system. } \\
\text { 3. I have no difficulty in using this fitness } \\
\text { training recommendation system. }\end{array}$ \\
\hline $\begin{array}{l}\text { Behaviora } \\
1 \text { Intention } \\
\text { to Use }\end{array}$ & $\begin{array}{l}\text { 1. I like the calculation feature to generate } \\
\text { fitness workout recommendations. } \\
\text { 2. I plan to use this application in the future. }\end{array}$ \\
\hline Actual Use & $\begin{array}{l}\text { 1. I use this recommendation system every } \\
\text { time I want to determine fitness training. } \\
\text { 2. I am satisfied with this fitness training } \\
\text { recommendation system. } \\
\text { 3. I like the process of using this } \\
\text { recommended application. } \\
\text { 4. I recommend using this fitness training } \\
\text { recommendation system to my friends. }\end{array}$ \\
\hline
\end{tabular}

From the results of the questionnaire, data was obtained to calculate the value of each assessment category based on the Technology Acceptance Model (TAM) testing model. The assessment categories assessed are Behavioral Intention to Use, Perceived Usefulness, Perceived Ease of Use, Actual Use, and Attitude toward Using. The calculation of the Perceived Usefulness category assessment can be seen in Table 8. 
Christian Prasetyo et al., International Journal of Emerging Trends in Engineering Research, 9(9), September 2021, 1234 - 1238

Table 8: Perceived Usefulness Calculation

\begin{tabular}{|c|l|c|}
\hline Questions & \multicolumn{1}{|c|}{ Calculation } & Result \\
\hline 1 & $\begin{array}{l}((7 * 5)+(25 * 4)+(3 * 3)+(0 * 2) \\
+(0 * 1) /(5 * 35)) * 100 \%\end{array}$ & $82.28 \%$ \\
\hline 2 & $\begin{array}{l}((11 * 5)+(19 * 4)+(5 * 3)+(0 * 2 \\
)+(0 * 1) /(5 * 35)) * 100 \%\end{array}$ & $83.42 \%$ \\
\hline
\end{tabular}

Calculation of the assessment of the Perceived Ease of Use category can be seen in Table 9 .

Table 9: Perceived Ease of Use Calculation

\begin{tabular}{|c|l|c|}
\hline Questions & \multicolumn{1}{|c|}{ Calculation } & Result \\
\hline 1 & $\begin{array}{l}((12 * 5)+(17 * 4)+(5 * 3)+(1 * 2 \\
\left.)+(0 * 1) /\left(5^{*} 35\right)\right) * 100 \%\end{array}$ & $82.85 \%$ \\
\hline 2 & $\begin{array}{l}((12 * 5)+(17 * 4)+(4 * 3)+(2 * 2 \\
)+(0 * 1) /(5 * 35)) * 100 \%\end{array}$ & $82.28 \%$ \\
\hline 3 & $\begin{array}{l}((15 * 5)+(15 * 4)+(4 * 3)+(1 * 2 \\
)+(0 * 1) /(5 * 35)) * 100 \%\end{array}$ & $85.14 \%$ \\
\hline
\end{tabular}

Calculation of the assessment of the Attitude toward using category can be seen in the following Table 10.

Table 10: Attitude toward Using Calculation

\begin{tabular}{|c|l|c|}
\hline Questions & \multicolumn{1}{|c|}{ Calculation } & Result \\
\hline 1 & $\begin{array}{l}((15 * 5)+(17 * 4)+(3 * 3)+(0 * 2 \\
)+(0 * 1) /(5 * 35)) * 100 \%\end{array}$ & $86.85 \%$ \\
\hline 2 & $\begin{array}{l}\left((12 * 5)+\left(18^{*} 4\right)+(3 * 3)+(1 * 2\right. \\
)+(1 * 1) /(5 * 35)) * 100 \%\end{array}$ & $82.28 \%$ \\
\hline 3 & $\begin{array}{l}((8 * 5)+(21 * 4)+(5 * 3)+(1 * 2) \\
+(0 * 1) /(5 * 35)) * 100 \%\end{array}$ & $80.57 \%$ \\
\hline
\end{tabular}

Calculation of the assessment of the Behavioral Intention to Use category can be seen in the following Table 11.

Table 11: Behavioral Intention to Use Calculation

\begin{tabular}{|c|l|c|}
\hline Questions & \multicolumn{1}{|c|}{ Calculation } & Result \\
\hline 1 & $\begin{array}{l}((17 * 5)+(13 * 4)+(5 * 3)+(0 * 2 \\
)+(0 * 1) /(5 * 35)) * 100 \%\end{array}$ & $86.85 \%$ \\
\hline 2 & $\begin{array}{l}((13 * 5)+(18 * 4)+(4 * 3)+(0 * 2 \\
)+(0 * 1) /(5 * 35)) * 100 \%\end{array}$ & $85.14 \%$ \\
\hline
\end{tabular}

The calculation of the Actual Use category assessment can be seen in the following Table 12.

Table 12: Actual Use Calculation

\begin{tabular}{|c|l|c|}
\hline Questions & \multicolumn{1}{|c|}{ Calculation } & Result \\
\hline 1 & $\begin{array}{l}((10 * 5)+(19 * 4)+(6 * 3)+(0 * 2 \\
)+(0 * 1) /(5 * 35)) * 100 \%\end{array}$ & $82.28 \%$ \\
\hline 2 & $\begin{array}{l}((11 * 5)+(19 * 4)+(4 * 3)+(1 * 2 \\
)+(0 * 1) /(5 * 35)) * 100 \%\end{array}$ & $82.85 \%$ \\
\hline 3 & $\begin{array}{l}((15 * 5)+(18 * 4)+(2 * 3)+(0 * 2 \\
)+(0 * 1) /(5 * 35)) * 100 \%\end{array}$ & $87.42 \%$ \\
\hline 4 & $\begin{array}{l}((11 * 5)+(19 * 4)+(5 * 3)+(0 * 2 \\
)+(0 * 1) /(5 * 35)) * 100 \%\end{array}$ & $83.42 \%$ \\
\hline
\end{tabular}

Next, the calculation of the average percentage of each assessment category is carried out as shown in Table 13.

Table 13: Final Percentage Calculation of each Category

\begin{tabular}{|c|c|c|}
\hline Category & \multicolumn{1}{|c|}{ Calculation } & Result \\
\hline $\begin{array}{c}\text { Perceived } \\
\text { Usefulness }\end{array}$ & $(82.28 \%+83.42 \%) / 2$ & $82.85 \%$ \\
\hline $\begin{array}{c}\text { Perceived } \\
\text { Ease of Use }\end{array}$ & $\begin{array}{l}(82.85 \%+82.28 \%+ \\
85.14 \%) / 3\end{array}$ & $83.42 \%$ \\
\hline $\begin{array}{c}\text { Attitude } \\
\text { Toward } \\
\text { Using }\end{array}$ & $(86.85 \%+82.28 \%+$ & $83.23 \%$ \\
\hline $\begin{array}{c}\text { Behavioral } \\
\text { Intention to } \\
\text { Use }\end{array}$ & $(80.57 \%) / 3$ & $85.99 \%$ \\
\hline Actual Use & $\begin{array}{l}(82.28 \%+82.85 \%+ \\
87.42 \%+83.42 \%) / 4\end{array}$ & $83.98 \%$ \\
\hline
\end{tabular}

Then the average percentage calculation is carried out to get the percentage of system success scores according to the following Table 14.

Table 14: Final Assessment Criteria

\begin{tabular}{|c|c|}
\hline Category & Description \\
\hline $0 \%-20 \%$ & Very Disagree \\
\hline $21 \%-40 \%$ & Agree \\
\hline $41 \%-60 \%$ & Neutral \\
\hline $61 \%-80 \%$ & Agree \\
\hline $81 \%-100 \%$ & Very Agree \\
\hline
\end{tabular}

Based on the average value of each category in the test model, the average value of $83.89 \%$ was obtained. Then the system gets the final assessment criteria Strongly Agree.

\section{CONCLUSION}

Based on the results of the research analysis conducted, the following conclusions can be drawn that, a fitness training recommendation system using the web-based Weighted Product method has been successfully created. The system displays a list of recommendations based on the calculation of the weight of the criteria selected by the user when using the application. The criteria used are tools, gender, time, and weight. And the system evaluation was carried out by distributing questionnaires to Multimedia Nusantara University students and school friends using the Technology Acceptance Model (TAM) and getting a final score of $83.89 \%$ so that it was included in the Strongly Agree category.

\section{FUTURE WORK}

Based on the research that has been done, there are several suggestions that can be made to develop the system, namely as 
Christian Prasetyo et al., International Journal of Emerging Trends in Engineering Research, 9(9), September 2021, 1234 - 1238

follows.

1. For further research, it is recommended to add other criteria that can be used for recommendations. This addition is intended so that the results of system recommendations can be more varied.

2. As a further comparative research material, it can be developed by using or combining other Multi Criteria Decision Making (MCDM) methods such as the Technique for Order Preference by Similarity to Ideal Solution (TOPSIS) method, or the Simple Additive Weighting (SAW) method so as to find a method that best to be implemented in a fitness training recommendation system.

\section{ACKNOWLEDGEMENT}

Thank you to the Universitas Multimedia Nusantara, Indonesia which has become a place for researchers to develop this journal research. Hopefully, this research can make a major contribution to the advancement of technology in Indonesia.

\section{REFERENCES}

1. V. Miñana-Signes and M. Monfort-Pañego, "The Conditioning of the Trunk Muscles and Back Health in Physical Education," Journal of Human Sport and Exercise, vol. 16, no. 3, pp. 640-651, 2021.

2. M. Leblanc, T. Linville, and M. Calkins, "Effectiveness of a Short-Term and Simple Exercise Training Program for Older Adults," Journal of Human Sport and Exercise, vol. 16, no. 3, pp. 721-736, 2021.

3. A. Setyono and S. N. Aeni, "Development of decision support system for ordering goods using fuzzy Tsukamoto," International Journal of Electrical and Computer Engineering, vol. 8, no. 2, pp. 1182-1193, 2018.

4. S. B. Basturk, C. E. J. Dancer, and T. McNally, "Effects of resistance training on insulin sensitivity in the elderly: A meta-analysis of randomized controlled trials," Pharmacological Research, p. 104743, 2020.

5. W. R. Thompson, "Worldwide Survey of Fitness Trends for 2021," ACSM's Health and Fitness Journal, vol. 25, no. 1, pp. 10-19, 2021.

6. D. Harris and S. Machek, "Theacrine as a Potential Caffeine Alternative for Enhanced Ergogenic and Cognitive Performance in Athletes: A Call to Action and Brief Review," Journal of Exercise and Nutrition, vol. 4, no. June, pp. 1-9, 2021.

7. A. C. Blackley and S. J. Arter, "Comparison of Peak Aerobic Capacity Between the Treadmill and a Skiing Ergometer," Journal of Exercise and Nutrition, vol. 4, no. 3, pp. 1-6, 2021.

8. A. Setyawan, F. Y. Arini, and I. Akhlis, "Comparative Analysis of Simple Additive Weighting Method and Weighted Product Method to New Employee Recruitment Decision Support System (DSS) at PT.
Warta Media Nusantara," Scientific Journal of Informatics, vol. 4, no. 1, pp. 34-42, 2017.

9. N. Aminudin et al., "Weighted Product and Its Application to Measure Employee Performance," International Journal of Engineering \& Technology, vol. 7, no. 2.26, p. 102, 2018.

10. Y. Zhu, "A data driven educational decision support system," International Journal of Emerging Technologies in Learning, vol. 13, no. 11, pp. 4-16, 2018.

11. R. A. Y. A. A. Wiseso and J. Setiawan, "Sistem Pendukung Keputusan Dalam Penentuan Penerima Beasiswa PT BFI Finance Indonesia Tbk Menggunakan Metode Profile Matching," Jurnal ULTIMA InfoSys, vol. 9, no. 1, pp. 51-57, 2018.

12. M. Megawaty and M. Ulfa, "Decision Support System Methods: A Review," Journal of Information Systems and Informatics, vol. 2, no. 1, pp. 192-201, 2020.

13. C. Fiarni, E. M. Sipayung, and P. B. T. Tumundo, "Academic Decision Support System for Choosing Information Systems Sub Majors Programs using Decision Tree Algorithm," Journal of Information Systems Engineering and Business Intelligence, vol. 5, no. 1, p. 57, 2019.

14. P. A. Jusia, Juliana, and Jasmir, "Decision Support System for Supplier Selection using Analytical Hierarchy Process ( AHP ) Method," Scientific Journal of Informatics, vol. 4, no. 2, pp. 1-6, 2017.

15. W. Philips, W. Istiono, and U. M. Nusantara, "Analysis of MinFinder Algorithm on Large Data Amounts," International Journal of Emerging Trends in Engineering Research, vol. 9, no. 6, pp. 627-632, 2021.

16. M. Apriyadi and S. Hansun, "Sistem Pendukung Keputusan Penerima Beasiswa UMN dengan Profile Matching," Jurnal ULTIMATICS, vol. 10, no. 1, pp. $1-6,2018$.

17. R. Webby and M. O'Connor, "The effectiveness of Decision Support Systems: The implications of task complexity and DSS sophistication," Journal of Information Technology, vol. 9, no. 1, pp. 19-28, 1994. 